\title{
Neurologica
}

\section{Gender differences in Parkinson's disease: A Clinical Perspective}

\begin{tabular}{|r|l|}
\hline Journal: & Acta Neurologica Scandinavica \\
\hline Manuscript ID & Draft \\
\hline Manuscript Type: & Review Article \\
\hline Therapy Areas: & Parkinson-s disease, Movement disorders \\
\hline Keywords: & $\begin{array}{l}\text { Parkinson's disease, Gender differences, Motor symptoms, Non-Motor } \\
\text { symptoms, Quality of life, Activities of daily living }\end{array}$ \\
\hline
\end{tabular}

\section{SCHOLARONE"}

Manuscripts 


\title{
Gender differences in Parkinson's disease: A Clinical Perspective
}

\author{
Dejan Georgiev ${ }^{1,2,5}$, Katarina Hamberg ${ }^{3}$ \\ Marwan Hariz ${ }^{2,4}$, Lars Forsgren ${ }^{4}$, Gun-Marie Hariz ${ }^{5}$ \\ ${ }^{1}$ Department of Neurology, University Clinical Centre Ljubljana, Slovenia \\ ${ }^{2}$ Sobell Department of Motor Neuroscience and Movement Disorders, Institute of \\ Neurology, University College London, UK \\ ${ }^{3}$ Departement of Public Health and Clinical Medicine, Family Medicine, Umeå \\ University, Sweden \\ ${ }^{4}$ Departement of Pharmacology and Clinical Neuroscience, Umeå University, Sweden \\ ${ }^{5}$ Departement of Community Medicine and Rehabilitation, Umeå University, Sweden \\ Correspondence to: \\ Dejan Georgiev, MD, PhD \\ University Medical Centre Ljubljana, Department of Neurology \\ Zaloška cesta 2, 1000 Ljubljana, Slovenia \\ dejan.georgiev@kclj.si \& dege0007@ad.umu.se
}

Word count title: 8

Word count abstract: 263

Word count text: 3665

Tables: 2

Figures: 0

References: 95 
Gender differences in $P D$, a review

\begin{abstract}
Available data indicate that there are gender differences in many features of Parkinson's disease (PD). Precise identification of the gender differences is important in order to tailor treatment, predict outcomes and meet other individual and social needs in women and men with PD. The aim of this paper was to review the available clinical data on gender differences in PD.

Original articles and meta-analyses published between 1990 and 2016 systematically exploring gender differences in PD were reviewed. There is slight male preponderance in incidence and prevalence of PD. PD starts earlier in men. Women tend to be more prone to develop tremor-dominant PD but are less rigid than men. Motor improvement after deep brain stimulation is equal in both sexes but women tend to show better improvement in activities of daily living. Furthermore, women with PD show better results on tests for general cognitive abilities, out-perform men in verbal cognitive tasks, show more pain symptoms and score higher on depression scales. It seems, however, that the differences in cognition, mood, and pain perception are not disease specific since similar gender differences can be found in healthy subjects and in other neurological conditions.

Despite PD being the most frequently studied movement disorder, studies investigating gender differences in PD are still scarce with most of the studies being cross sectional. Good quality, prospective, longitudinal studies analyzing gender differences in PD and comparing them to matched healthy controls are needed in order to properly address the issues of gender differences in PD.
\end{abstract}

Keywords: Parkinson's disease, gender differences, motor symptoms, nonmotor symptoms, quality of life, activities of daily living. 
Gender differences in $P D$, a review

\section{Introduction}

Parkinson's disease (PD) is a chronic neurodegenerative disease. Its main pathological feature is degeneration of substantia nigra pars compacta ( $\mathrm{SNc}$ ) leading to reduced dopamine production. ${ }^{1}$ This, together with degeneration of other brain regions, subsequently leads to resting tremor, rigidity, brady-hypokinesia, and postural instability, which are the main motor manifestations of the disease. ${ }^{2}$ In addition, there is an abundance of non-motor symptoms (NMS), such as hyposmia, constipation, REM sleep behaviour disorder (RBD), pain, depression and cognitive disturbances that also contribute to disability in activities of daily living (ADL) and decreased quality of life $(\mathrm{QoL}){ }^{3}$

Available data indicate that there are gender differences in many features of PD. Not only epidemiological characteristics of the disease differ between men and women with PD, but there are also differences in clinical presentation of both the motor and non-motor features of the disease. ${ }^{4}$ Taking these differences in consideration might help diagnosis, tailor treatment, predict outcomes and meet social and other needs in men and women with PD. ${ }^{5}$ Despite PD being the most frequently studied movement disorder, studies investigating gender differences in PD are still scarce. In addition, it is not clear how clinically relevant the already described gender differences in PD are in order to be used to differentially diagnose and treat PD. In this paper we will use the term gender in its broader sense - encompassing both the biological (i.e. sex) differences as well as the social, cultural and personal implications of what it means to be a woman or a man (i.e. gender), keeping in mind that both terms - sex and gender- have often been used interchangeably in the medical literature. ${ }^{6}$

The main aim of this paper is to review the clinical studies systematically 
Gender differences in $P D$, a review

exploring gender differences in PD. Because of paucity of data, gender differences in other parkinsonisms are not reviewed here (Table $\left.1^{7-9}\right)$. We will first look at the gender differences in epidemiology (incidence, prevalence, age at onset), and then move to gender differences in both motor and non-motor clinical presentations (cognition, depression, anxiety, apathy, fatigue, pain, autonomic dysfunction, hyposmia, sleep) as well as explore differences in ADL/QoL measures and in treatment of PD.

\section{Materials and methods}

Search of the literature was performed on PubMed, Web of Science, and Scopus. The search terms included Parkinson's disease, sex, gender, motor, nonmotor symptoms (cognition, depression, anxiety, apathy, fatigue, pain, autonomic dysfunction, hyposmia, sleep), epidemiology, demographic characteristics, activities of daily living, and quality of life. The criteria used to extract the relevant papers included original articles and meta-analyses systematically exploring gender differences in PD from 1990 to 2016.

The search initially rendered 238 papers without duplicates. After excluding papers on basic and animal studies, 184 papers remained. Of these 62 met the criteria above and were included in this systematic review (see Table 1 for summary of studies and Table 2 for gender distribution of symptoms and signs). All authors approved the extraction of the relevant articles.

\section{Results and discussion}


Gender differences in $P D$, a review

\subsection{Gender differences in incidence, prevalence, age at onset and risk factors in PD patients}

In most of the studies reviewed here the number of men with PD outweighed the number of women (Table 1). The total number of women with PD in the reviewed articles was 12994 (41\%), and the total number of men with PD was 18302 (59\%). Indeed, one of the most commonly reported gender differences in PD is that women are less likely to get PD. For example, Baldereschi et al. ${ }^{10}$ reported greater incidence of $\mathrm{PD}$ in men $(41.1 / 10,0000$ annually) than in women $(21.7 / 10,000$ annually) including all age groups. This has been replicated in other studies. ${ }^{11-13}$ In addition, the prevalence is also higher in men than in women with PD (around 30/10,000 and $24 / 10,000$ respectively), ${ }^{13-15}$ and according to some studies, men have up to twice as higher risk than women to develop PD. ${ }^{16-18}$

Regarding the age at disease onset, even though some studies have found that PD starts earlier in men, ${ }^{19,20}$ others showed no difference between sexes in mean age at PD onset and age at PD diagnosis. ${ }^{21}$ Similar findings were reported by Baba et al. $2005^{22}$ and Scott et al. ${ }^{23}$ who also found no differences in age at disease onset and duration of symptoms before diagnosis, or disease duration from diagnosis between sexes. Risk factors for PD did also differ in men and women; for example Savica et $\mathrm{al}^{24}$ found that in men risks included lack of coffee consumption, head trauma, and exposure to pesticides, while anemia was a risk factor in women. In a recent study, high urate levels in men but not in women was associated with lower future risk to develop PD. ${ }^{25}$ Regarding gender differences in genetic risk factors to develop PD the studies are not consistent: while some studies report a female preponderance in leucine-rich repeat kinase 2 (LRRK2) positive $\mathrm{PD},{ }^{26}$ other studies did not find any gender differences. ${ }^{27}$ Interestingly, having a child with LRRK2 mutation seems to be 
related to higher risk of PD in the parents, as does having a daughter no matter the genetic status of the offspring. ${ }^{28}$ Genetic influence might also have a gender specific effect on environmental risk factors such as smoking; for example, monoamineoxidase B (MAO-B) genotype was shown to have a modifying effect on the inverse relationship between smoking and PD in men, but not in women. ${ }^{29}$ In addition, there is also evidence that there might be gender-related differences in gene expression in human dopaminergic neurons in SNc (e.g. up-regulation of alpha-synuclein and PTEN induced kinase 1 (PINK1) genes in men, but not in women ${ }^{30}$ ), which might at least partially explain the gender differences in clinical presentation and response to treatment in $\mathrm{PD} .^{31,32}$ No gender differences in incidence/prevalence or other disease characteristics have been reported for parkin ${ }^{33}$ or glucocerebrosidase (GBA) genes. ${ }^{34}$

In conclusion, there is evidence suggesting that men are at higher risk to develop PD. The reason behind this is not well understood. Some data suggest that this might be related to the protective role of oestrogens in women, ${ }^{35,36}$ as the incidence of PD becomes more even across sexes in postmenopausal women. ${ }^{37}$ The gender difference in prevalence and incidence of PD might also result from different profiles of risk factors, environmental ${ }^{24}$ and/or genetic. ${ }^{26}$ An alternative explanation may be that most studies rely on a 'hospital-clinical population', meaning that there may already be a selection bias at the point of patient recruitment, and even though women tend to be more prone to participate in research ${ }^{38}$ in many countries men may have better access to health care. ${ }^{39}$ When using 'door to door survey' methodology the figures seem to show either no gender difference in prevalence, ${ }^{40,41}$ or sometimes even higher prevalence of $\mathrm{PD}$ in women ${ }^{42}$ Furthermore, data concerning an earlier PD onset in men compared to women are not conclusive and need further clarification.

\subsection{Gender differences in motor symptoms, disease progression and}


As the motor symptoms still form the basis for PD diagnosis, it is interesting to evaluate gender differences in presentation of motor symptoms (Tables 1 and 2). Indeed, knowledge about possible gendered patterns in disease manifestation may make the diagnosis of PD in men and women easier. It seems that women experience later onset of motor symptoms ${ }^{11}$ and they are also more likely to present with tremor dominant PD. ${ }^{20,43}$ Tremor dominant PD is know to be associated with a slower and more benign disease progression, ${ }^{1}$ although the overall motor scores may not necessarily show gender differences. ${ }^{20}$ Women also show higher striatal dopaminergic $\operatorname{activity}^{20,44,45}$ and healthy women even show higher dopaminergic synthetic capacity compared to age-matched healthy men. ${ }^{46}$ Other motor symptoms such as writing difficulties and clumsiness were found to be less frequent in women than in men with PD. ${ }^{23}$ On the other hand, Augustine et al. ${ }^{21}$ did not find differences in motor symptoms and neither in time spent with dyskinesias nor in time spent "off" medication, or in occurrence of early morning dystonia. Similarly, Baba et al. $2005^{22}$ did not find gender differences in the distribution of tremor and bradykinesia in the initial phase of PD, although a higher proportion of women showed a Hoehn and Yahr (H\&Y) score above three suggesting more advanced disease at inclusion in women. Furthermore, even though there was no gender difference in the overall motor scores of the Unified Parkinson's Disease rating Scale (UPDRS), women had worse scores in postural instability and had lower rigidity scores, ${ }^{13,43,47}$ while the rate of disease progression was similar in both sexes. ${ }^{22}$ Greater overall severity of motor symptoms in men and worse dyskinesias in women, despite lower L-dopa equivalence daily dose $(L E D D)^{13,22,47-49}$ (see Umeh et al. ${ }^{50}$ for alternative findings) have also been shown in other studies. ${ }^{47,51}$ In addition, dyskinesias in women occurred earlier after disease 
Gender differences in $P D$, a review

onset than in men. ${ }^{52}$

Other drug-related motor phenomena are also reported to be more frequent in women. For example, Colombo et al. ${ }^{53}$ found a higher prevalence of wearing-offs (WOFs) in women, which together with higher rate of dyskinesias and shorter latency to develop dyskinesias might be explained by greater L-dopa bioavailability ${ }^{54}$ and better response to L-dopa in women. ${ }^{51}$ Similar findings were reported in other studies. ${ }^{55,56}$ However, despite higher L-dopa bioavailability in women with PD, Kompoliti et al. ${ }^{55}$ did not find gender differences in bioavailability of pramipexole, and found no difference in clinical improvement after L-dopa administration. No gender differences in motor symptoms but higher proportion of non-motor fluctuations in women with PD were recently reported by Picillo et al. $2016 .^{57}$

In conclusion, it seems that women with PD may have more favorable disease profile since motor symptoms emerge later, tremor is more common as first presenting symptom ${ }^{20}$ and women with PD tend to be less rigid $^{22}$ Some data, however, suggest that women are more prone to develop postural instability than men. ${ }^{22}$ Even though treatment with dopamine agonists (DA) does not differ between men and women, ${ }^{50}$ it seems that L-dopa related motor complications, such as dyskinesias and WOFs are more common in women with PD. ${ }^{53}$

\subsection{Gender differences in non-motor symptoms, and other disease characteristics in PD patients}

In addition to the motor symptoms and signs, non-motor symptoms (NMS) and signs form an integral part of the disease manifestations. ${ }^{58}$ Possible gender 
Gender differences in $P D$, a review

differences in NMS in PD patients ${ }^{59,60}$ could substantially improve the gender-specific approach in diagnosis and treatment. In addition, NMS do indeed affect patients' ADL and QoL.

\subsubsection{Gender differences in cognition}

According to Augustine et al. ${ }^{21}$ men show worse cognitive abilities as measured by the overall scores on the Symbol Digit Modalities and the Scale for Outcome of Parkinson Disease Cognition. Worse general cognitive abilities in men with PD have been reported in other studies as well ${ }^{47,61}$ It seems that there is also domain specific gender difference patterns in cognition, such that men with PD show worse performance on verbal memory tests but better visuospatial abilities. ${ }^{61,62}$ Similar pattern (i.e. faster psychomotor speed and higher verbal memory and learning in women, but better visuospatial abilities in men) has been reported in healthy elderly men, ${ }^{61,63}$ in patients with mild cognitive impairments without $\mathrm{PD}^{64,65}$ and in patients with Alzheimer's disease,${ }^{65}$ although some may dispute the validity of these test results in female healthy population (e.g. that tests of spatial abilities are not gender neutral $\left.{ }^{66}\right)$. Contrary to these findings Gao et al. ${ }^{51}$ found lower scores on a number of cognitive tests in women with PD: in addition to the cognitive domains "traditionally" being reported to be better in men (visuospatial or mathematical abilities), men with PD performed better than women on vocabulary tasks as well. However, in this study men had a higher level of education than women with PD. Furthermore, Foltynie et al. ${ }^{67}$ investigating the effect of different alleles for the Val ${ }^{66}$ Met polymorphism for the Brain Derived Neurotrophic Factor (BDNF) gene, found that women with PD with Met alleles for the gene performed better on the 
Gender differences in $P D$, a review

Tower of London test, suggesting better executive functions in female patients carriers of the Met allele. Interestingly, Caranci et al. ${ }^{68}$ found association between lower plasma levels of alpha synuclein and cognitive impairment, hallucinations, psychosis and apathy in men with advanced-stage PD, but not in women.

\subsubsection{Gender differences in depression, anxiety, apathy, fatigue and pain}

Baba et al. $2005^{22}$ reported a significantly higher proportion of depression in women with PD. Similar findings have been reported in other studies ${ }^{13,23,43,51,69-72}$, even though this has not been always replicated. ${ }^{73}$ As a matter of caution, it is well known that in general, women are more prone to develop depression. ${ }^{74,75}$ Interestingly in a 2-years follow-up study Picillo et al. $2014^{48}$ found significant reduction of depression in both sexes. Higher anxiety level, ${ }^{43,51,61,70,72}$ higher prevalence of fatigue $^{43,69}$ and higher proportion of NMS fluctuations (despite no difference in LEDD) $)^{57}$ in women with PD has also been consistently reported. Meyer et al. ${ }^{76}$ found that older age correlated positively with apathy in men, but negatively in women, suggesting a reduced risk of apathy in older women. It also seems that PD related pain symptoms are more prevalent in women ${ }^{13,23,69}$, which again might not be disease specific as this can be seen also in the general population. ${ }^{77,78}$

\subsubsection{Gender differences in sleep/REM-sleep behaviour disorders (RBD)}

Bjørnara et al. $^{79}$ explored the gender differences with regards to $R B D$. Although the prevalence of RBD was higher in men, the difference was not significant. A higher prevalence of RBD in men with PD has been reported in other 
studies as well, ${ }^{47}$ with men showing more fights, violent behaviour and awaking by own movements. Male preponderance has also been noted in idiopathic RBD. ${ }^{80}$ Other studies have, however, reported higher rate in night-time sleep disturbances in women with PD. ${ }^{13}$

\subsubsection{Autonomic dysfunction and hyposmia}

It seems that sexual dysfunction is more prevalent in men with PD. ${ }^{13,43,47,70,72}$ Related to this, compulsive sexual behavior, a part of the impulse control disorders (ICD) spectrum, is known to be more frequent in men with PD. ${ }^{81}$ In addition to low dopamine agonist dose, female gender was found to be a good prognostic factor for ICD resolution. ${ }^{82}$ Unlike men, women with PD are more prone to develop impulsive shopping and binge eating. ${ }^{81}$ Urinary symptoms have been reported to be more frequent in men, ${ }^{48,69}$ which holds true also for hyposmia. ${ }^{61,72}$ On the other hand, orthostatic hypotension, cardiovascular problems ${ }^{13}$ and weight $\operatorname{loss}^{83}$ have been found to be more common in women with $\mathrm{PD}$, although these results (e.g. orthostatic hypotension) are not unequivocal. ${ }^{47}$

\subsubsection{Activities of daily living (ADL) and quality of life (QoL)}

Lubomski et al. ${ }^{84}$ evaluated the gender differences in QoL related to motor symptoms in PD. In this study, men reported a greater disease burden than women as noted by higher UPDRS-III scores, higher LEDD and higher reliance on caregivers. The Parkinson's Disease Questionnaire (PDQ-39) showed men having lower QoL in the ADL, cognition and communication domains. On the other hand, Baba et al. 
Gender differences in $P D$, a review

$2005^{22}$ found worse ADLs in women with PD; however improvement of ADL in women after deep brain stimulation (DBS), has been shown to be greater than in men with PD. ${ }^{85,86}$ Lower QoL in women with PD has been reported in other studies as well. ${ }^{13,87}$

In conclusion, there is strong evidence that NMS profiles differ between men and women with PD. One of the most consistent gender differences in the NMS in PD are in the cognitive abilities; it seems that women with PD show better global cognitive abilities than men. ${ }^{61}$ While women with PD usually perform better on verbal memory and learning tests, men have better visuospatial abilities. ${ }^{61}$ However, it is important to note again that similar pattern of gender-specific differences in cognitive abilities has been described not only in patients with other neurological disorders. ${ }^{64,65}$ but also in healthy subjects, ${ }^{61,63}$. Similarly, higher level of depression and anxiety in women is not PD-specific ${ }^{48,61,72}$ since it is also seen in the general population. ${ }^{74,75}$ In addition higher prevalence of chronic pain states and greater pain sensitivity among women in the general population has also been repeatedly reported. ${ }^{77,78}$ Sexual dysfunction and urinary difficulties are more common in men with PD. In general, the overall QoL and ADL might be more affected in women with PD. ${ }^{84-86}$

\subsection{Gender differences in PD patients treated with stereotactic surgery}

There are only few studies reporting gender differences in patients treated with stereotactic surgery. In a meta-analysis Hariz G-M et al. $2011,{ }^{88}$ (see also Hariz G-M et al. $2003,{ }^{86}$ Kenny et al. $2007,{ }^{89}$ and Chiou et al. $2015^{90}$ ) evaluated the distribution of PD patients treated with subthalamic nucleus (STN) deep brain stimulation (DBS). They screened 135 publications with respect to the gender distribution of patients 
Gender differences in $P D$, a review

treated with STN DSB across different continents. Patients' gender was specified in 119 papers (88\%), encompassing a total of 3880 patients, of whom $2445(63 \%)$ were men. Hence the number of men with PD treated with stereotactic surgery in this metaanalysis exceeded the "usual" male/ female predominance in PD. ${ }^{10}$ In an earlier study Hariz G-M et al. $2003^{86}$ explored the gender differences in QoL measures in PD patients before and after stereotactic treatment for PD. Before surgery women had a longer disease course, higher stage of disease on the H\&Y scale, higher scores of UPDRS-II (ADL) and IV (complications of therapy), worse scores on the ADL taxonomy and on Schwab and England ADL scale. Even though motor improvement was similar in both sexes (see also Hariz G-M et al. $2003,{ }^{86}$ Accolla et al. $2007,{ }^{49}$ and Chiou et al. $2015^{90}$ for gender-related equal motor improvement), 11 months after surgery women showed significantly better improvement in ADL, emotions and social life. This was replicated in later studies from the same, ${ }^{85}$ and other groups. ${ }^{49}$ In addition, while lower LEDD, higher motor dysfunction (particularly tremor), and greater improvement in tremor and rigidity on L-dopa challenge test were found to predict better operative outcome in men with $\mathrm{PD}^{90}$, better ADL scores, despite higher preoperative motor scores, predicted better operative outcome in women with PD. ${ }^{90}$

In summary, the evidence from the studies on gender differences in PD patients treated with stereotactic surgery suggest that men are more likely than women to access surgical treatment, ${ }^{85}$ which may be related to a gendered referral bias for surgery favoring men, ${ }^{88}$ or due to women declining surgery. ${ }^{91}$ Interestingly, despite the same motor improvement across sexes, ${ }^{85}$ QoL measures and ADL improve more in women than in men, although women have longer disease duration before surgery than men. ${ }^{85,92}$ 
Gender differences in $P D$, a review

\section{Conclusions and directions for future research}

The aim of this paper was to review clinical studies exploring the gender differences in PD. The data from the studies reviewed here indicate that there are many potential markers for gender differences in PD. Candidate markers sensitive to gender differences in PD can be found not only amongst epidemiological characteristics and the motor symptoms, but also amongst non-motor symptoms of the disease. In addition, data also suggest differences in QoL and ADL measures of PD (Table 2).

Summarizing, one of the best established disease characteristics that shows a gender specific effect is the slightly higher incidence and prevalence of PD among male subjects. ${ }^{10}$ In addition, it seems that PD starts earlier in men compared to women possibly due to the protective effect that oestrogen has in pre-menopausal women. ${ }^{20}$ Women more often show tremor-dominant PD at disease onset compared to men. ${ }^{20}$ It also seems that women are less rigid $^{22}$ but display more postural instability than men. ${ }^{22,43}$ Even though the therapy scheme and LEDD seem to be similar in men and women with $\mathrm{PD},{ }^{50}$ (or sometimes reported to be even higher in men, ${ }^{22}$ probably due to better bioavailability of L-dopa in women than men) women are more prone to develop dyskinesias than men. ${ }^{22,43}$ Regarding NMS in PD, while in general women show better results on measures of general cognitive abilities as well as on verbal memory and executive tasks, ${ }^{61}$ men show better visuospatial cognitive abilities. ${ }^{61}$ On the other hand, women with PD show higher level of depression and anxiety. ${ }^{22}$ These findings should, however, be interpreted with caution, since a similar gender specific pattern concerning these non-motor domains has been reported in the healthy population, ${ }^{61,63,74,75,77,78}$ as well as in patients with other neurological conditions. ${ }^{64,65}$ Even though response of motor symptoms to DBS seems to be similar in men and women with PD, ADL improve more in women. ${ }^{85}$ 
Gender differences in $P D$, a review

There are few important issues that have to be taken into consideration when planning future research on gender differences in PD: controlled, prospective, longitudinal studies specifically looking at the issue of gender differences in clinical presentation of PD (see Picillo et al. 2014, ${ }^{48}$ a short-term follow-up study on gender differences in PD) are lacking. Possible changes over time might be expected not only quantitatively (i.e. severity of symptoms), but also in the quality/ gender-related pattern of symptoms and signs. This can also trigger potential research on the basic mechanisms that underlie these changes. ${ }^{93}$ Furthermore, it is important to compare results in PD with matched healthy subjects, as many characteristics that account for the gender differences seen in general population are also reflected in PD. ${ }^{61}$ Therefore, future studies on the gender differences in PD (and other neurological disorders) should always include comparison with matched healthy controls, as this may have important implications for the interpretation of gender differences in PD and other neurological conditions.

Aside from this review, good quality basic studies specifically exploring the issue of gender differences in PD at different levels - molecular, cellular, network, and system level are needed. For example, there are only few studies on gender differences in the electrophysiological characteristics of the disease. ${ }^{94}$ There is also lack of studies directly correlating possible basic mechanisms and clinically observable gender differences in PD (translational research). Therefore, good quality (basic and clinical) studies on gender differences in PD may lead to identification of reliable gender-sensitive markers that can be used to approach patients in a genderspecific manner - from diagnosis, through treatment to addressing socioeconomic issues related to PD. Indeed, there is a continuous need for research about gender bias in medical investigations and treatments in everyday clinical practice in general ${ }^{95}$ with 
Gender differences in $P D$, a review

a final aim to better improve the quality of life and wellbeing of all patients, irrespective of gender.

Acknowledgements: This study was supported by The Strategic Research Area in Care Sciences (SFO-V), Umeå University and The Swedish Research Council (SRC). MH and the UCL Unit of Functional Neurosurgery are supported by the Parkinson Appeal UK and the Monument Trust.

Conflict of interest and financial disclosures: the authors report no conflict of interest and no financial disclosures. 
Gender differences in $P D$, a review

\section{References}

1. Lees AJ, Hardy J, Revesz T. Parkinson's disease. Lancet. 2009;373(9680):2055-2066.

2. Muller CM, de Vos RA, Maurage CA, Thal DR, Tolnay M, Braak H. Staging of sporadic Parkinson disease-related alpha-synuclein pathology: inter- and intra-rater reliability. Journal of neuropathology and experimental neurology. 2005;64(7):623-628.

3. Chaudhuri KR, Healy DG, Schapira AH, National Institute for Clinical E. Non-motor symptoms of Parkinson's disease: diagnosis and management. The Lancet Neurology. 2006;5(3):235-245.

4. Pavon JM, Whitson HE, Okun MS. Parkinson's disease in women: a call for improved clinical studies and for comparative effectiveness research. Maturitas. 2010;65(4):352-358.

5. Young LJ, Pfaff DW. Sex differences in neurological and psychiatric disorders. Frontiers in neuroendocrinology. 2014;35(3):253-254.

6. Risberg G, Johansson EE, Hamberg K. A theoretical model for analysing gender bias in medicine. International journal for equity in health. 2009;8:28.

7. Baba Y, Putzke JD, Whaley NR, Wszolek ZK, Uitti RJ. Progressive supranuclear palsy: phenotypic sex differences in a clinical cohort. Movement disorders : official journal of the Movement Disorder Society. 2006;21(5):689-692.

8. Caslake R, Taylor K, Scott N, et al. Age-, and gender-specific incidence of vascular parkinsonism, progressive supranuclear palsy, and parkinsonian-type multiple system atrophy in North East Scotland: the PINE study. Parkinsonism \& related disorders. 2014;20(8):834-839.

9. Yamamoto T, Sakakibara R, Uchiyama T, et al. Time-dependent changes and gender differences in urinary dysfunction in patients with multiple system atrophy. Neurourology and urodynamics. 2014;33(5):516-523. 
Gender differences in $P D$, a review

10. Baldereschi M, Di Carlo A, Rocca WA, et al. Parkinson's disease and parkinsonism in a longitudinal study: two-fold higher incidence in men. ILSA Working Group. Italian Longitudinal Study on Aging. Neurology. 2000;55(9):1358-1363.

11. Alves G, Muller B, Herlofson K, et al. Incidence of Parkinson's disease in Norway: the Norwegian ParkWest study. Journal of neurology, neurosurgery, and psychiatry. 2009;80(8):851-857.

12. Linder J, Stenlund H, Forsgren L. Incidence of Parkinson's disease and parkinsonism in northern Sweden: a population-based study. Movement disorders : official journal of the Movement Disorder Society. 2010;25(3):341-348.

13. Kovacs M, Makkos A, Aschermann Z, et al. Impact of Sex on the Nonmotor Symptoms and the Health-Related Quality of Life in Parkinson's Disease. Parkinson's disease. 2016;2016:7951840.

14. Mayeux R, Marder K, Cote LJ, et al. The frequency of idiopathic Parkinson's disease by age, ethnic group, and sex in northern Manhattan, 1988-1993. American journal of epidemiology. 1995;142(8):820-827.

15. Wooten GF. Are men at greater risk for Parkinson's disease than women? Journal of Neurology, Neurosurgery \& Psychiatry. 2004;75(4):637-639.

16. Elbaz A, Bower JH, Maraganore DM, et al. Risk tables for parkinsonism and Parkinson's disease. Journal of clinical epidemiology. 2002;55(1):25-31.

17. de Lau LM, Giesbergen PC, de Rijk MC, Hofman A, Koudstaal PJ, Breteler MM. Incidence of parkinsonism and Parkinson disease in a general population: the Rotterdam Study. Neurology. 2004;63(7):1240-1244.

18. Van Den Eeden SK, Tanner CM, Bernstein AL, et al. Incidence of Parkinson's disease: variation by age, gender, and race/ethnicity. American journal of epidemiology. 2003;157(11):1015-1022. 
Gender differences in $P D$, a review

19. Martinez-Rumayor A, Arrieta O, Sotelo J, Garcia E. Female gender but not cigarette smoking delays the onset of Parkinson's disease. Clinical neurology and neurosurgery. 2009;111(9):738-741.

20. Haaxma CA, Bloem BR, Borm GF, et al. Gender differences in Parkinson's disease. Journal of neurology, neurosurgery, and psychiatry. 2007;78(8):819824.

21. Augustine EF, Perez A, Dhall R, et al. Sex Differences in Clinical Features of Early, Treated Parkinson's Disease. PloS one. 2015;10(7):e0133002.

22. Baba Y, Putzke JD, Whaley NR, Wszolek ZK, Uitti RJ. Gender and the Parkinson's disease phenotype. Journal of neurology. 2005;252(10):12011205.

23. Scott B, Borgman A, Engler H, Johnels B, Aquilonius SM. Gender differences in Parkinson's disease symptom profile. Acta neurologica Scandinavica. 2000;102:37-43.

24. Savica R, Grossardt BR, Bower JH, Ahlskog JE, Rocca WA. Risk factors for Parkinson's disease may differ in men and women: an exploratory study. Hormones and behavior. 2013;63(2):308-314.

25. Gao X, O’Reilly EJ, Schwarzschild MA, Ascherio A. Prospective study of plasma urate and risk of Parkinson disease in men and women. Neurology. 2016;86(6):520-526.

26. Cilia R, Siri C, Rusconi D, et al. LRRK2 mutations in Parkinson's disease: confirmation of a gender effect in the Italian population. Parkinsonism \& related disorders. 2014;20(8):911-914.

27. Gan-Or Z, Leblond CS, Mallett V, Orr-Urtreger A, Dion PA, Rouleau GA. LRRK2 mutations in Parkinson disease; a sex effect or lack thereof? A metaanalysis. Parkinsonism \& related disorders. 2015;21(7):778-782.

28. Saunders-Pullman R, Stanley K, San Luciano M, et al. Gender differences in the risk of familial parkinsonism: beyond LRRK2? Neuroscience letters. 2011;496(2):125-128. 
Gender differences in $P D$, a review

29. Kelada SN, Costa-Mallen P, Costa LG, et al. Gender Difference in the Interaction of Smoking and Monoamine Oxidase B Intron 13 Genotype in Parkinson's Disease. NeuroToxicology. 2002;23:515-519.

30. Cantuti-Castelvetri I, Keller-McGandy C, Bouzou B, et al. Effects of gender on nigral gene expression and parkinson disease. Neurobiology of disease. 2007 26(3):606-614.

31. Trabzuni D, A. R, Imran S, et al. Widespread sex differences in gene expression and splicing in the adult human brain. Nat Commun. 2013;4:2771.

32. Simunovic F, Yi M, Wang Y, Stephens R, Sonntag KC. Evidence for genderspecific transcriptional profiles of nigral dopamine neurons in Parkinson disease. PloS one. 2010;5(1):e8856.

33. Nishioka K, Kefi M, Jasinska-Myga B, et al. A comparative study of LRRK2, PINK1 and genetically undefined familial Parkinson's disease. Journal of neurology, neurosurgery, and psychiatry. 2010;81(4):391-395.

34. Chahine LM, Qiang J, Ashbridge E, et al. Clinical and biochemical differences in patients having Parkinson disease with vs without GBA mutations. JAMA Neurol. 2013;70(7):852-858.

35. Shulman LM. Gender Differences in Parkinson's Disease. Gender Medicine. 2007;4(2):8-18.

36. Miller IN, Cronin-Golomb A. Gender Differences in Parkinson's Disease: Clinical Characteristics and Cognition. Movement Disorders. 2010;25(16):2695-2703.

37. Nitkowska M, Czyzyk M, Friedman A. Reproductive life characteristics in females affected with Parkinson's disease and in healthy control subjects - a comparative study on Polish population. Neurologia i neurochirurgia polska. 2014;48(5):322-327.

38. Galea S, Tracy M. Participation rates in epidemiologic studies. Annals of epidemiology. 2007;17(9):643-653. 
Gender differences in $P D$, a review

39. Tanner CM, Goldman SM. Epidemiology of Parkinson's disease. Neurologic clinics. 1996;14(2):317-335.

40. Bergareche A, De La Puente E, Lopez de Munain A, et al. Prevalence of Parkinson's disease and other types of Parkinsonism. A door-to-door survey in Bidasoa, Spain. Journal of neurology. 2004;251(3):340-345.

41. de Rijk M, C., Tzourio C, Breteler MM, et al. Prevalence of parkinsonism and Parkinson's disease in Europe: the EUROPARKINSON Collaborative Study. European Community Concerted Action on the Epidemiology of Parkinson's disease. Journal of neurology, neurosurgery, and psychiatry. 1997;62(1):1015.

42. Nicoletti A, Sofia V, Bartoloni A, et al. Prevalence of Parkinson's disease: a door-to-door survey in rural Bolivia. Parkinsonism \& related disorders. 2003;10(1):19-21.

43. Solla P, Cannas A, Ibba FC, et al. Gender differences in motor and non-motor symptoms among Sardinian patients with Parkinson's disease. Journal of the neurological sciences. 2012;323(1-2):33-39.

44. Kotagal V, Albin RL, Muller ML, Koeppe RA, Frey KA, Bohnen NI. Gender differences in cholinergic and dopaminergic deficits in Parkinson disease. $J$ Neural Transm (Vienna). 2013;120(10):1421-1424.

45. Lee JJ, Ham JH, Lee PH, Sohn YH. Gender Differences in Age-Related Striatal Dopamine Depletion in Parkinson's Disease. Journal of movement disorders. 2015;8(3):130-135.

46. Laakso A, Vilkman H, Bergman J, et al. Sex differences in striatal presynaptic dopamine synthesis capacity in healthy subjects. Biological psychiatry. 2002;52(7):759-763.

47. Szewczyk-Krolikowski K, Tomlinson P, Nithi K, et al. The influence of age and gender on motor and non-motor features of early Parkinson's disease: initial findings from the Oxford Parkinson Disease Center (OPDC) discovery cohort. Parkinsonism \& related disorders. 2014;20(1):99-105. 
Gender differences in $P D$, a review

48. Picillo M, Erro R, Amboni $\mathrm{M}$, et al. Gender differences in non-motor symptoms in early Parkinson's disease: a 2-years follow-up study on previously untreated patients. Parkinsonism \& related disorders. 2014;20(8):850-854.

49. Accolla E, Caputo E, Cogiamanian F, et al. Gender differences in patients with Parkinson's disease treated with subthalamic deep brain stimulation. Movement disorders : official journal of the Movement Disorder Society. 2007;22(8):1150-1156.

50. Umeh CC, Perez A, Augustine EF, et al. No sex differences in use of dopaminergic medication in early Parkinson disease in the US and Canada baseline findings of a multicenter trial. PloS one. 2014;9(12):e112287.

51. Gao L, Nie K, Tang H, et al. Sex differences in cognition among Chinese people with Parkinson's disease. Journal of clinical neuroscience : official journal of the Neurosurgical Society of Australasia. 2015;22(3):488-492.

52. Hassin-Baer S, Molchadski I, Cohen OS, et al. Gender effect on time to levodopa-induced dyskinesias. Journal of neurology. 2011;258(11):20482053.

53. Colombo D, Abbruzzese G, Antonini A, et al. The "gender factor" in wearingoff among patients with Parkinson's disease: a post hoc analysis of DEEP study. TheScientificWorldJournal. 2015;2015:787451.

54. Kumagai T, Nagayama H, Ota T, Nishiyama Y, Mishina M, Ueda M. Sex differences in the pharmacokinetics of levodopa in elderly patients with Parkinson disease. Clinical neuropharmacology. 2014;37(6):173-176.

55. Kompoliti K, Adler CH, Raman R, et al. Gender and pramipexole effects on levodopa pharmacokinetics and pharmacodynamics. Neurology. 2002;58:1418-1422.

56. Olanow CW, Kieburtz K, Rascol O, et al. Factors predictive of the development of Levodopa-induced dyskinesia and wearing-off in Parkinson's 
Gender differences in $P D$, a review

disease. Movement disorders : official journal of the Movement Disorder Society. 2013;28(8):1064-1071.

57. Picillo M, Palladino R, Moccia M, et al. Gender and non motor fluctuations in Parkinson's disease: A prospective study. Parkinsonism \& related disorders. 2016;27:89-92.

58. Postuma RB, Berg D, Stern M, et al. MDS clinical diagnostic criteria for Parkinson's disease. Movement disorders : official journal of the Movement Disorder Society. 2015;30(12):1591-1601.

59. Kim SR, So HY, Choi E, Kang JH, Kim HY, Chung SJ. Influencing effect of non-motor symptom clusters on quality of life in Parkinson's disease. Journal of the neurological sciences. 2014;347(1-2):310-315.

60. Heller J, Dogan I, Schulz JB, Reetz K. Evidence for gender differences in cognition, emotion and quality of life in Parkinson's disease? Aging and disease. 2014;5(1):63-75.

61. Liu R, Umbach DM, Peddada SD, et al. Potential sex differences in nonmotor symptoms in early drug-naive Parkinson disease. Neurology. 2015;84(21):2107-2115.

62. Carey JR, Deskin KA, Josephson KT, Wichmann RL. Sex differences in tracking performance in patients with Parkinson's disease. Archives of physical medicine and rehabilitation. 2002;83(7):972-977.

63. Munro CA, Winicki JM, Schretlen DJ, et al. Sex differences in cognition in healthy elderly individuals. Neuropsychology, development, and cognition Section B, Aging, neuropsychology and cognition. 2012;19(6):759-768.

64. Sundermann EE, Biegon A, Rubin LH, et al. Better verbal memory in women than men in MCI despite similar levels of hippocampal atrophy. Neurology. 2016;86(15):1368-1376.

65. Sundermann EE, Maki PM, Rubin LH, et al. Female advantage in verbal memory: Evidence of sex-specific cognitive reserve. Neurology. 2016. 
Gender differences in $P D$, a review

66. Hamberg K. Biology, gender and behaviour. A critical discussion of the biological models used for explaining cognitive and behavioural gender differences. In: Lee JW, ed. Psychology of gender identity. New York: Noca Science Publisher, Inc; 2005:127-144.

67. Foltynie T, Lewis SG, Goldberg TE, et al. The BDNF Val66Met polymorphism has a gender specific influence on planning ability in Parkinson's disease. Journal of neurology. 2005;252(7):833-838.

68. Caranci G, Piscopo P, Rivabene R, et al. Gender differences in Parkinson's disease: focus on plasma alpha-synuclein. $J$ Neural Transm (Vienna). 2013;120(8):1209-1215.

69. Guo X, Song W, Chen K, et al. Gender and onset age-related features of nonmotor symptoms of patients with Parkinson's disease--a study from Southwest China. Parkinsonism \& related disorders. 2013;19(11):961-965.

70. Martinez-Martin P, Falup Pecurariu C, Odin P, et al. Gender-related differences in the burden of non-motor symptoms in Parkinson's disease. Journal of neurology. 2012;259(8):1639-1647.

71. Song Y, Gu Z, An J, Chan P, Chinese Parkinson Study G. Gender differences on motor and non-motor symptoms of de novo patients with early Parkinson's disease. Neurological sciences : official journal of the Italian Neurological Society and of the Italian Society of Clinical Neurophysiology. 2014;35(12):1991-1996.

72. Picillo M, Amboni M, Erro R, et al. Gender differences in non-motor symptoms in early, drug naive Parkinson's disease. Journal of neurology. 2013;260(11):2849-2855.

73. van der Hoek TC, Bus BA, Matui P, van der Marck MA, Esselink RA, Tendolkar I. Prevalence of depression in Parkinson's disease: effects of disease stage, motor subtype and gender. Journal of the neurological sciences. 2011;310(1-2):220-224. 
Gender differences in $P D$, a review

74. Hankin BL, Abramson LY. Development of gender differences in depression: an elaborated cognitive vulnerability-transactional stress theory. Psychological bulletin. 2001;127(6):773-796.

75. Nolen-Hoeksema S, Larson J, Grayson C. Explaining the gender difference in depressive symptoms. Journal of personality and social psychology. 1999;77(5):1061-1072.

76. Meyer A, Zimmermann R, Gschwandtner U, et al. Apathy in Parkinson's disease is related to executive function, gender and age but not to depression. Frontiers in aging neuroscience. 2014;6:350.

77. Wiesenfeld-Hallin Z. Sex differences in pain perception. Gend Med. 2005;2(3):137-145.

78. Mylius V, Kunz M, Schepelmann K, Lautenbacher S. Sex differences in nociceptive withdrawal reflex and pain perception. Somatosensory \& motor research. 2005;22(3):207-211.

79. Bjørnara KA, Dietrichs E, Toft M. REM sleep behavior disorder in Parkinson's disease--is there a gender difference? Parkinsonism \& related disorders. 2013;19(1):120-122.

80. Postuma RB, Gagnon JF, Vendette M, Fantini ML, Massicotte-Marquez J, Montplaisir J. Quantifying the risk of neurodegenerative disease in idiopathic REM sleep behavior disorder. Neurology. 2009;72(15):1296-1300.

81. Weintraub D, Koester J, Potenza MN, et al. Impulse control disorders in Parkinson disease: a cross-sectional study of 3090 patients. Archives of neurology. 2010;67(5):589-595.

82. Joutsa J, Martikainen K, Vahlberg T, Kaasinen V. Effects of dopamine agonist dose and gender on the prognosis of impulse control disorders in Parkinson's disease. Parkinsonism \& related disorders. 2012;18(10):1079-1083.

83. Walker R, Davidson M, Gray W. Gender differences in 1-year survival rates after weight loss in people with idiopathic Parkinson's disease. International Journal of Palliative Nursing. 2012;18(1):35-39. 
Gender differences in $P D$, a review

84. Lubomski M, Louise Rushworth R, Lee W, Bertram KL, Williams DR. Sex differences in Parkinson's disease. Journal of clinical neuroscience : official journal of the Neurosurgical Society of Australasia. 2014;21(9):1503-1506.

85. Hariz GM, Limousin P, Zrinzo L, et al. Gender differences in quality of life following subthalamic stimulation for Parkinson's disease. Acta neurologica Scandinavica. 2013;128(4):281-285.

86. Hariz GM, Lindberg M, Hariz MI, Bergenheim AT. Gender differences in disability and health-related quality of life in patients with Parkinson's disease treated with stereotactic surgery. Acta neurologica Scandinavica. 2003;108:28-37.

87. Moore O, Kreitler S, Ehrenfeld M, Giladi N. Quality of life and gender identity in Parkinson's disease. Journal of neural transmission. 2005;112(11):1511-1522.

88. Hariz GM, Nakajima T, Limousin P, et al. Gender distribution of patients with Parkinson's disease treated with subthalamic deep brain stimulation; a review of the 2000-2009 literature. Parkinsonism \& related disorders. 2011;17(3):146-149.

89. Kenney C, Simpson R, Hunter C, et al. Short-term and long-term safety of deep brain stimulation in the treatment of movement disorders. Journal of neurosurgery. 2007;106(4):621-625.

90. Chiou SM. Sex-Related Prognostic Predictors for Parkinson Disease Undergoing Subthalamic Stimulation. World neurosurgery. 2015;84(4):906912.

91. Hamberg K, Hariz GM. The decision-making process leading to deep brain stimulation in men and women with parkinson's disease - an interview study. BMC neurology. 2014;14:89.

92. Hariz GM, Hariz MI. Gender distribution in surgery for Parkinson's disease. Parkinsonism and Related Disorders. 2000;6:155-157. 
Gender differences in $P D$, a review

93. McCarthy MM, Arnold AP, Ball GF, Blaustein JD, De Vries GJ. Sex differences in the brain: the not so inconvenient truth. The Journal of neuroscience : the official journal of the Society for Neuroscience. 2012;32(7):2241-2247.

94. Marceglia S, Mrakic-Sposta S, Foffani G, et al. Gender-related differences in the human subthalamic area: a local field potential study. The European journal of neuroscience. 2006;24(11):3213-3222.

95. Hamberg K. Gender bias in medicine. Women's health. 2008;4(3):237-243. 


\begin{tabular}{|c|c|c|c|c|c|c|c|c|c|c|}
\hline \multirow{2}{*}{\multicolumn{2}{|c|}{2}} & \multirow{2}{*}{$\begin{array}{l}\text { First author, } \\
\text { year [Ref No] }\end{array}$} & \multicolumn{2}{|c|}{ Participants } & \multirow[t]{2}{*}{ Main objectives/ Study type } & \multirow[t]{2}{*}{ DEM } & \multirow[t]{2}{*}{ MS } & \multirow[t]{2}{*}{ NMS } & \multirow{2}{*}{$\begin{array}{l}\text { ADL/ } \\
\text { QoL }\end{array}$} & \multirow[t]{2}{*}{ Summary of main gender-related results } \\
\hline & & & F: N (\%) & M: N (\%) & & & & & & \\
\hline $\begin{array}{l}3 \\
4 \\
5\end{array}$ & 1 & $\begin{array}{l}\text { Accola et al. } \\
2007^{49}\end{array}$ & $16(42)$ & $22(58)$ & $\begin{array}{l}\text { To evaluate gender differences } \\
\text { in STN-DBS PD patients before } \\
\text { and } 1 \text { year post-op/ Prospective } \\
\text { controlled study } \\
\end{array}$ & $\mathrm{X}$ & $\mathrm{X}$ & $\mathrm{X}$ & $\mathrm{X}$ & Higher improvement of ADLs in women \\
\hline 8 & 2 & $\begin{array}{l}\text { Augustine et } \\
\text { al. } 2015^{21}\end{array}$ & $618(31)$ & $1,123(63)$ & $\begin{array}{l}\text { To evaluate gender differences } \\
\text { in PD/ Cross sectional study }\end{array}$ & $\mathrm{X}$ & $\mathrm{X}$ & $\mathrm{X}$ & $\mathrm{X}$ & $\begin{array}{l}\text { No gender difference in age at disease onset, women performed better on } \\
\text { cognitive tests (SCales for Outcomes in PArkinson's disease-COGnition - } \\
\text { SCOPA-COG) }\end{array}$ \\
\hline $\begin{array}{c}9 \\
10 \\
11\end{array}$ & 3 & $\begin{array}{l}\text { Alves et al. } \\
2009^{11}\end{array}$ & $85(41)$ & $122(59)$ & $\begin{array}{l}\text { To explore gender differences } \\
\text { and incidence of PD/ } \\
\text { Longitudinal study } \\
\end{array}$ & $\mathrm{X}$ & $\mathrm{X}$ & & & $\begin{array}{l}\text { Standardized male to female ratio } 1.58 \text { with a consistent male preponderance and } \\
\text { an incidence of } 15.6 / 10^{5 \mathrm{y}-1} \text { in men and } 9.9 / 10^{5 \mathrm{yy}-1}\end{array}$ \\
\hline 14 & & $\begin{array}{l}\text { Baba et al. } \\
2006^{7}\end{array}$ & PSP: 68 (56) & PSP: 53 (44) & $\begin{array}{l}\text { To evaluate sex differences in } \\
\text { PSP/ Cross sectional study }\end{array}$ & $\mathrm{X}$ & $\mathrm{X}$ & & & Men had higher tremor score and higher body-mass index \\
\hline $\begin{array}{l}15 \\
16 \\
17\end{array}$ & 6 & $\begin{array}{l}\text { Baldereschi et } \\
\text { al. } 2000^{10}\end{array}$ & $29(69)$ & $13(31)$ & $\begin{array}{l}\text { To determine incidence of } \\
\text { parkinsonism and PD/ } \\
\text { Longitudinal study }\end{array}$ & $\mathrm{X}$ & & & & Men showed higher PD prevalence in all age groups \\
\hline $\begin{array}{l}18 \\
19\end{array}$ & & $\begin{array}{l}\text { Bergareche et } \\
\text { al. } 2004^{40}\end{array}$ & $\begin{array}{l}\text { PD:12 (66) } \\
\text { OP: } 7(50)\end{array}$ & $\begin{array}{l}\text { PD: } 6(33) \\
\text { OP: } 7(50)\end{array}$ & $\begin{array}{l}\text { Door-to-door survey of PD and } \\
\text { other parkinsonisms }\end{array}$ & $\mathrm{X}$ & & & & No gender difference in prevalence of PD \\
\hline $\begin{array}{l}20 \\
21 \\
22 \\
23\end{array}$ & & $\begin{array}{l}\text { Bjørnarå et al. } \\
2013^{79}\end{array}$ & $42(39.2)$ & $68(63.5)$ & $\begin{array}{l}\text { To examine possible PD gender } \\
\text { differences with regards to } \\
\text { RBD symptoms/Controlled } \\
\text { study }\end{array}$ & & $\mathrm{X}$ & $\mathrm{X}$ & & $\begin{array}{l}\text { More women experienced disturbed sleep, more men experiences fights, violent } \\
\text { behaviour and awakings by own movements }\end{array}$ \\
\hline $\begin{array}{r}24 \\
25 \\
26\end{array}$ & & $\begin{array}{l}\text { Cantuti- } \\
\text { Castelvetri et } \\
\text { al. } 2007^{30}\end{array}$ & $\begin{array}{l}\text { PD: } 4(50) \\
\text { HC: } 4(50)\end{array}$ & \begin{tabular}{|l|l|} 
PD: $4(50)$ \\
HC: $4(50)$
\end{tabular} & $\begin{array}{l}\text { To evaluate gender-specific } \\
\text { gene expression in PD/ In vitro } \\
\text { post mortem study }\end{array}$ & & & & 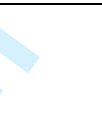 & $\begin{array}{l}\text { Alpha-synuclein and PINK1 genes in substantia nigra upregulated in men, but } \\
\text { not in women with PD }\end{array}$ \\
\hline $\begin{array}{r}27 \\
28 \\
29 \\
30\end{array}$ & 10 & $\begin{array}{l}\text { Caranci et al. } \\
2013^{68}\end{array}$ & $\begin{array}{l}\text { PD: } 40(57) \\
\text { HC: } 53(51)\end{array}$ & $\begin{array}{l}\text { PD: } 29(43) \\
\text { HC: } 50(49)\end{array}$ & $\begin{array}{l}\text { To examine PD gender } \\
\text { differences in alpha-synuclein } \\
\text { plasma concentrations/ } \\
\text { Controlled study } \\
\end{array}$ & $\mathrm{X}$ & & $\mathrm{X}$ & & Plasma alpha-synuclein concentrations in advanced PD decreased in men \\
\hline $\begin{array}{r}31 \\
32 \\
33\end{array}$ & 11 & $\begin{array}{l}\text { Caslake et al. } \\
2014^{8}\end{array}$ & $\begin{array}{l}\text { VP: } 14(37) \\
\text { PSP: } 3(18) \\
\text { MSA: } 10(50)\end{array}$ & $\begin{array}{l}\text { VP: } 24(63) \\
\text { PSP:14 (82) } \\
\text { MSA: } 10(50)\end{array}$ & $\begin{array}{l}\text { To examine demographic } \\
\text { characteristics of degenerative } \\
\text { and vascular parkinsonisms/ } \\
\text { Cross sectional study }\end{array}$ & $\mathrm{X}$ & & & & $\begin{array}{l}\text { Age adjusted male to female ratios for VP } 2.58,1.49 \text { for PSP and } 8.65 \text { for MSA. } \\
\text { No differences in other clinical or socio-demographic data }\end{array}$ \\
\hline $\begin{array}{r}34 \\
35 \\
36\end{array}$ & 12 & $\begin{array}{l}\text { Carey et al. } \\
2002^{62}\end{array}$ & $\begin{array}{l}\text { PD: } 10(50) \\
\text { HC: } 10(50)\end{array}$ & $\begin{array}{l}\text { PD: } 10(50) \\
\text { HC:10(50) }\end{array}$ & $\begin{array}{l}\text { To examine possible PD gender } \\
\text { differences in tracking } \\
\text { performance/ Controlled study }\end{array}$ & & & $\mathrm{X}$ & & No gender difference in tracking performance in PD \\
\hline $\begin{array}{r}37 \\
38 \\
39\end{array}$ & 13 & $\begin{array}{l}\text { Chahine et al. } \\
2013^{34}\end{array}$ & $80(30)$ & $182(70)$ & $\begin{array}{l}\text { To examine clinical and } \\
\text { biochemical differences in PD } \\
\text { in GBA mutations/ } \\
\text { Epidemiological study }\end{array}$ & $\mathrm{X}$ & $\mathrm{X}$ & & & $\begin{array}{l}\text { No gender differences, GBA patients have earlier age at onset and are more } \\
\text { likely to demonstrate cognitive deficit. }\end{array}$ \\
\hline $\begin{array}{r}40 \\
41 \\
42\end{array}$ & & $\begin{array}{l}\text { Chiou et al. } \\
2015^{90}\end{array}$ & $48(66)$ & $24(34)$ & $\begin{array}{l}\text { To examine gender differences } \\
\text { in motor symptoms in STN- } \\
\text { DBS PD patients/ Prospective } \\
\end{array}$ & $\mathrm{X}$ & & & & $\begin{array}{l}\text { Women had slightly lower MMSE scores and better response to L-dopa before } \\
\text { operation; no gender differences in the response of motor symptoms to STN- } \\
\text { DBS }\end{array}$ \\
\hline
\end{tabular}




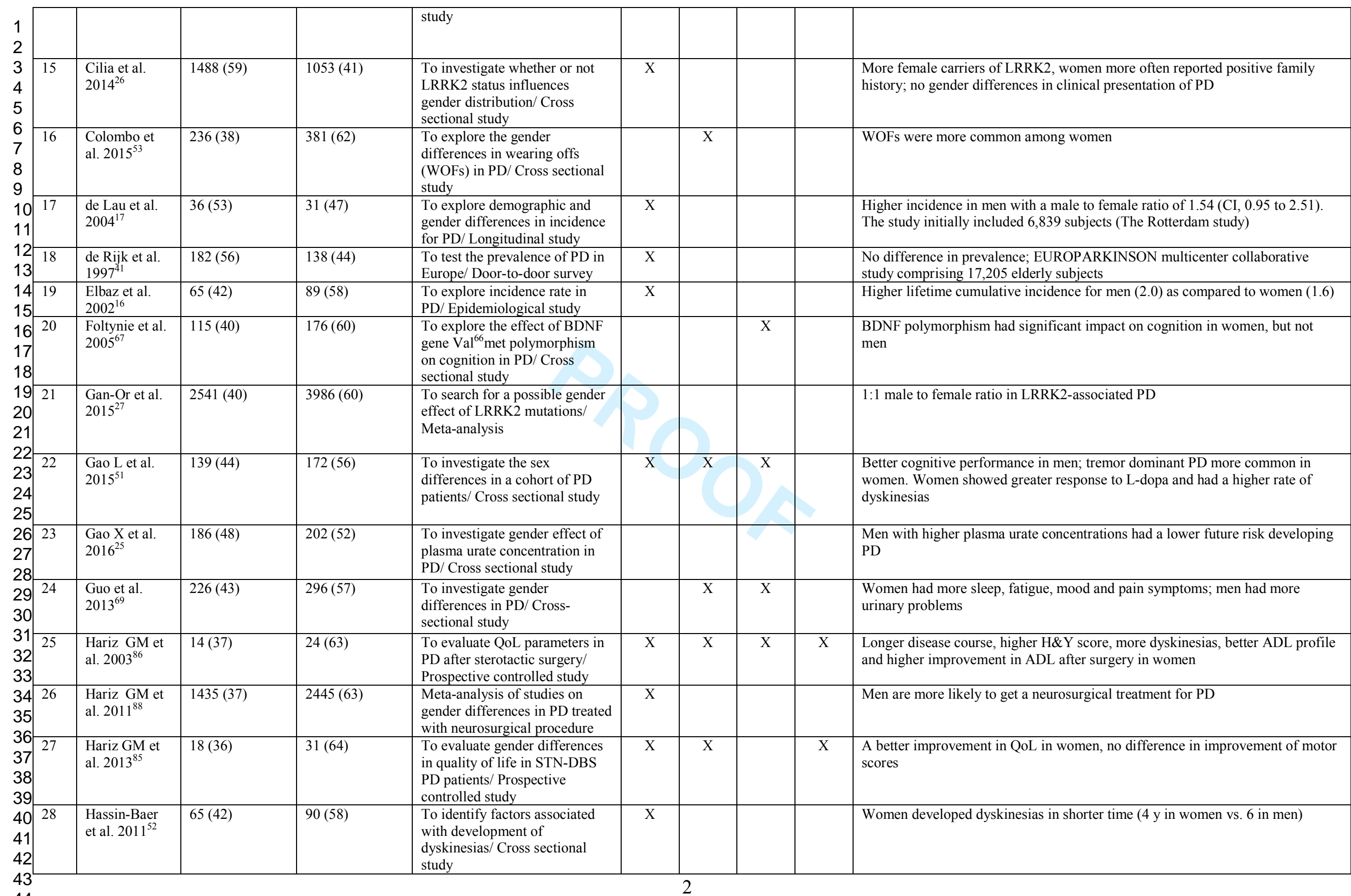




\begin{tabular}{|c|c|c|c|c|c|c|c|c|c|c|}
\hline $\begin{array}{l}1 \\
2\end{array}$ & 29 & $\begin{array}{l}\text { Haaxma et al. } \\
2007^{20}\end{array}$ & $99(39)$ & $154(61)$ & $\begin{array}{l}\text { To investigate the gender } \\
\text { differences in PD/ Cross } \\
\text { sectional study }\end{array}$ & $\mathrm{X}$ & $\mathrm{X}$ & & & $\begin{array}{l}\text { Women were older at disease onset, showed more tremor dominant phenotype } \\
\text { and higher striatal traces uptake on DATScan }\end{array}$ \\
\hline $\begin{array}{l}3 \\
4 \\
5\end{array}$ & 30 & $\begin{array}{l}\text { Joutsa et al. } \\
2012^{82}\end{array}$ & $109(38)$ & $181(62)$ & $\begin{array}{l}\text { To investigate the prognostic } \\
\text { factors for ICD resolution/ } \\
\text { Cross sectional study }\end{array}$ & & & $\mathrm{X}$ & & Female gender was been found to be a good prognostic factor for ICD resolution \\
\hline $\begin{array}{l}6 \\
7 \\
8\end{array}$ & 31 & $\begin{array}{l}\text { Kelada et al. } \\
2002^{29}\end{array}$ & $\begin{array}{l}\text { PD: } 73(39) \\
\text { HC: } 103(35)\end{array}$ & $\begin{array}{l}\text { PD: } 113(61) \\
\text { HC: } 193(65)\end{array}$ & $\begin{array}{l}\text { To test if gender can modify the } \\
\text { associations between smoking, } \\
\text { MAO-B intron } 13 \text { genotype, } \\
\text { and PD }\end{array}$ & $\mathrm{X}$ & & & & $\begin{array}{l}\text { MAO-B intron } 13 \text { genotype has an effect on the inverse relation between } \\
\text { smoking and PD in men, but not in women }\end{array}$ \\
\hline $\begin{array}{l}9 \\
10 \\
11\end{array}$ & 32 & $\begin{array}{l}\text { Kim et al. } \\
2014^{59}\end{array}$ & $74(40)$ & $108(60)$ & $\begin{array}{l}\text { To investigate NMS gender } \\
\text { differences in PD/ Cross } \\
\text { sectional study }\end{array}$ & $\mathrm{X}$ & $\mathrm{X}$ & $\mathrm{X}$ & & $\begin{array}{l}\text { Different profile of NMS in men and women with PD defined by different } \\
\text { content of clusters }\end{array}$ \\
\hline $\begin{array}{l}12 \\
13 \\
14\end{array}$ & 33 & $\begin{array}{l}\text { Kompoliti et } \\
\text { al. } 2002^{55}\end{array}$ & $14(53)$ & $12(47)$ & $\begin{array}{l}\text { To study sex differences on the } \\
\text { phar- macokinetics of L-dopa } \\
\text { and paramipexole/ Cross } \\
\text { sectional study }\end{array}$ & & & & & $\begin{array}{l}\text { Postmenopausal women had higher bioavailability of L-dopa; no gender } \\
\text { difference in bioavailability of paramipexole, no difference in clinical } \\
\text { improvement after levodopa }\end{array}$ \\
\hline $\begin{array}{l}15 \\
16 \\
17\end{array}$ & 34 & $\begin{array}{l}\text { Kotagal et al. } \\
2013^{44}\end{array}$ & $36(25)$ & $112(75)$ & $\begin{array}{l}\text { To investigate gender } \\
\text { differences in dopaminergic and } \\
\text { cholinergic denervation in PD/ } \\
\text { Cross sectional study }\end{array}$ & & & & & $\begin{array}{l}\text { Men showed greater caudate dopaminergic denervation and greater neocortical } \\
\text { cholinergic denervation than women }\end{array}$ \\
\hline $\begin{array}{l}18 \\
19 \\
20\end{array}$ & 35 & $\begin{array}{l}\text { Kovacs et al. } \\
2016^{13}\end{array}$ & $361(58)$ & $360(42)$ & $\begin{array}{l}\text { To investigate NMS sex } \\
\text { differences in PD/ Cross } \\
\text { sectional study }\end{array}$ & $\mathrm{X}$ & $\mathrm{X}$ & $\mathrm{X}$ & & $\begin{array}{l}\text { PD more prevalent in men; man had higher dose of DM, and more sexual } \\
\text { problems; women had worse postural instability, gait disabilities, and } \\
\text { dyskinesias, and worse non-motor symptoms and HRQoL }\end{array}$ \\
\hline 21 & 36 & $\begin{array}{l}\text { Kumagai et al. } \\
2014^{54}\end{array}$ & $77(60)$ & $51(40)$ & $\begin{array}{l}\text { To test gender differences in } \\
\text { bioavailability of L-dopa/ } \\
\text { Interventional clinical study }\end{array}$ & $\mathrm{X}$ & & & & Women have a greater bioavailability of L-dopa than men \\
\hline $\begin{array}{l}23 \\
24 \\
25 \\
26 \\
27 \\
20\end{array}$ & 37 & $\begin{array}{l}\text { Laakso et al. } \\
2002^{46}\end{array}$ & HC:12 (34) & HC: 23 (66) & $\begin{array}{l}\text { To test the hypothesis of higher } \\
\text { presynaptic dopamine function } \\
\text { in healthy women by [18F]F- } \\
\text { DOPA PET/ Cross sectional } \\
\text { study }\end{array}$ & & & & & $\begin{array}{l}\text { Healthy premenopausal women have a higher striatal presynaptic dopamine } \\
\text { synthesis capacity than healthy men; a relative decrease in dopamine activity } \\
\text { with age in men but not in women }\end{array}$ \\
\hline 29 & 38 & $\begin{array}{l}\text { Lee et al. } \\
2015^{45}\end{array}$ & $155(51)$ & $152(49)$ & $\begin{array}{l}\text { To compare gender differences } \\
\text { in DAT activity by using } 18 \mathrm{~F}- \\
\text { FP-CIT in healthy subjects }\end{array}$ & & & & & $\begin{array}{l}\text { Women showed greater DAT activity in the striatum; age-related DAT decline } \\
\text { was greater in the striatum in women }\end{array}$ \\
\hline $\begin{array}{l}31 \\
32 \\
33\end{array}$ & 39 & $\begin{array}{l}\text { Linder et al. } \\
2010^{12}\end{array}$ & $76(54)$ & $62(46)$ & $\begin{array}{l}\text { To investigate the incidence of } \\
\text { parkinsonism/ Cross sectional } \\
\text { study }\end{array}$ & $\mathrm{X}$ & $\mathrm{X}$ & $\mathrm{X}$ & $\mathrm{X}$ & $\begin{array}{l}\text { Higher incidence of PD in men (male to female ratio=1.2); higher H\&Y score in } \\
\text { women }\end{array}$ \\
\hline $\begin{array}{l}34 \\
35 \\
36\end{array}$ & 40 & $\begin{array}{l}\text { Liu et al. } \\
2015^{61}\end{array}$ & $\begin{array}{l}\text { PD: } 145(35) \\
\text { HC: } 67(35)\end{array}$ & $\begin{array}{l}\text { PD: } 269(65) \\
\text { HC } 121(65)\end{array}$ & $\begin{array}{l}\text { To examine gender differences } \\
\text { in non-motor symptoms of drug } \\
\text { naïve PD patients/ Cross } \\
\text { sectional study }\end{array}$ & $\mathrm{X}$ & $\mathrm{X}$ & $\mathrm{X}$ & $\mathrm{X}$ & $\begin{array}{l}\text { Men had significantly more olfaction deficits and worse global and verbal } \\
\text { cognitive performance; women were more depressed and showed worse } \\
\text { visuospatial deficits. Similar cognitive profile in HC }\end{array}$ \\
\hline $\begin{array}{l}37 \\
38 \\
39\end{array}$ & 41 & $\begin{array}{l}\text { Lubomski et } \\
\text { al. } 2014^{84}\end{array}$ & $81(38)$ & $129(62)$ & $\begin{array}{l}\text { To evaluate gender differences } \\
\text { in } \mathrm{PD} / \text { Cross sectional study }\end{array}$ & $\mathrm{X}$ & & $\mathrm{X}$ & $\mathrm{X}$ & $\begin{array}{l}\text { Men had higher motor scores, higher daily dopaminergic medication intake, } \\
\text { lower QoL, worse ADLs and showed higher impact of disease on overall life. }\end{array}$ \\
\hline 40 & 42 & $\begin{array}{l}\text { Marceglia et } \\
\text { al. } 2006^{94}\end{array}$ & $12(50)$ & $12(50)$ & $\begin{array}{l}\text { To explore gender differences } \\
\text { in LFP activity in STN in PD } \\
\text { patients/ Controlled study }\end{array}$ & & & & & $\begin{array}{l}\text { LFP recordings at rest without DM showed significantly higher power in the } \\
\text { alpha/low-beta band in women and also had higher increase in high gamma } \\
\text { activity after dopaminergic medication }\end{array}$ \\
\hline 42 & 43 & Martinez- & $123(51)$ & $120(49)$ & To determine if smoking or & $\mathrm{X}$ & & & & Female gender, but not smoking delayed disease onset \\
\hline
\end{tabular}




\begin{tabular}{|c|c|c|c|c|c|c|c|c|c|c|}
\hline $\begin{array}{l}1 \\
2\end{array}$ & & $\begin{array}{l}\text { Rumayor et } \\
\text { al. } 2009^{19}\end{array}$ & & & $\begin{array}{l}\text { other factors (sex) determine } \\
\text { age at PD onset/ } \\
\text { Epidemiological study }\end{array}$ & & & & & \\
\hline $\begin{array}{l}3 \\
4 \\
5\end{array}$ & 44 & $\begin{array}{l}\text { Martinez- } \\
\text { Martin et al. } \\
2012^{70}\end{array}$ & $356(37)$ & $595(63)$ & $\begin{array}{l}\text { To explore gender differences } \\
\text { in NMS in PD patients/ Cross } \\
\text { sectional study }\end{array}$ & $\mathrm{X}$ & $\mathrm{X}$ & $\mathrm{X}$ & $\mathrm{X}$ & $\begin{array}{l}\text { Women reported more fatigue, were more depressed and anxious, and had more } \\
\text { pain; men had more sleeping and sexual problems }\end{array}$ \\
\hline $\begin{array}{l}7 \\
8\end{array}$ & 45 & $\begin{array}{l}\text { Moore et al. } \\
2005^{87}\end{array}$ & $55(45)$ & $69(55)$ & $\begin{array}{l}\text { To explore the effect of gender } \\
\text { identity on quality of life in PD/ } \\
\text { Cross sectional controlled study }\end{array}$ & $\mathrm{X}$ & & & $\mathrm{X}$ & $\begin{array}{l}\text { The QoL of androgynous PD women was significantly better than the } \\
\text { androgynous PD men group }\end{array}$ \\
\hline 9 & 46 & $\begin{array}{l}\text { Nicoletti et al. } \\
2003^{42}\end{array}$ & $3(60)$ & $2(40)$ & $\begin{array}{l}\text { To explore the demographic } \\
\text { characteristics of PD/ Door-to- } \\
\text { door survey }\end{array}$ & $\mathrm{X}$ & & & & $\begin{array}{l}\text { In the population aged } 40 \text { years and above prevalence was higher in women than } \\
\text { in men ( } 323 \text { and } 248 / 100,000 \text {, respectively) }\end{array}$ \\
\hline $\begin{array}{c}17 \\
12 \\
13 \\
14 \\
15 \\
16\end{array}$ & 47 & $\begin{array}{l}\text { Nishioka et al. } \\
2010^{33}\end{array}$ & $38(13)$ & $193(83)$ & $\begin{array}{l}\text { To compare clinical } \\
\text { characteristic between } \\
\text { genetically neutral PD and PD } \\
\text { related to LRRK2, PKAN1 and } \\
\text { parkin mutations/ Cross } \\
\text { sectional study }\end{array}$ & $\mathrm{X}$ & $\mathrm{X}$ & & & No gender differences related to genes found \\
\hline $\begin{array}{l}10 \\
17 \\
18 \\
19\end{array}$ & 48 & $\begin{array}{l}\text { Picillo et al. } \\
2013^{72}\end{array}$ & $\begin{array}{l}\text { PD: } 74(37) \\
\text { HC: } 33(35)\end{array}$ & $\begin{array}{l}\text { PD: } 126(63) \\
\text { HC: } 60(65)\end{array}$ & $\begin{array}{l}\text { To explore the gender } \\
\text { differences in NMS in PD drug } \\
\text { naïve patients/ Cross sectional } \\
\text { study }\end{array}$ & $\mathrm{X}$ & & $\mathrm{X}$ & & Men with PD reported more sex and taste/smelling difficulties \\
\hline $\begin{array}{l}20 \\
21 \\
22\end{array}$ & 49 & $\begin{array}{l}\text { Picillo et al. } \\
2014^{48}\end{array}$ & $48(35)$ & $86(65)$ & $\begin{array}{l}\text { To explore gender differences } \\
\text { in PD patients in } 2 \text { years } \\
\text { follow-up period/ Longitudinal } \\
\text { follow-up study }\end{array}$ & $\mathrm{X}$ & $\mathrm{X}$ & $\mathrm{X}$ & & $\begin{array}{l}\text { Men had higher LEDD doses, and complained of greater number of NMS; } \\
\text { Men reported more urgency, daytime sleepiness, weight change and sex drive. A } \\
\text { reduction of mood/depressive symptoms in both sexes. }\end{array}$ \\
\hline $\begin{array}{l}23 \\
24 \\
25 \\
26\end{array}$ & 50 & $\begin{array}{l}\text { Picillo et al. } \\
2016^{57}\end{array}$ & $16(34)$ & $31(66)$ & $\begin{array}{l}\text { To evaluate the gender } \\
\text { differences in non-motor } \\
\text { fluctuations in PD/Longitudinal } \\
\text { prospective study }\end{array}$ & & $\mathrm{X}$ & $\mathrm{X}$ & & $\begin{array}{l}\text { Women had higher motor UPDRS scores, and had more non-motor fluctuations } \\
\text { compared to men, no differences in motor fluctuations }\end{array}$ \\
\hline \begin{tabular}{l|}
27 \\
28 \\
29 \\
30 \\
31
\end{tabular} & 51 & $\begin{array}{l}\text { Saunders- } \\
\text { Pullman, et al. } \\
2011^{28}\end{array}$ & $82(46)$ & $93(54)$ & $\begin{array}{l}\text { To test whether there is an } \\
\text { increased genetic component } \\
\text { (LRRK2 G2019S) of PD in } \\
\text { women of Jewish background/ } \\
\text { Cross sectional study }\end{array}$ & & & & & $\begin{array}{l}\text { Having a daughter with PD associated with increased risk of parkinsonism in the } \\
\text { parent as was having a child with a LRRK2 G2019S mutation }\end{array}$ \\
\hline $\begin{array}{l}32 \\
33 \\
34\end{array}$ & 52 & $\begin{array}{l}\text { Savica et al. } \\
2013^{24}\end{array}$ & $75(38)$ & $121(62)$ & $\begin{array}{l}\text { To explore the gender } \\
\text { differences in risk factors in } \\
\text { PD/ Retrospective study }\end{array}$ & & & & & $\begin{array}{l}\text { Risk factors for PD and their interactions may differ in men and women. In men } \\
\text { independent effects of lack of coffee consumption, head trauma, and pesticide } \\
\text { use; in women, anemia was the most important risk factor }\end{array}$ \\
\hline \begin{tabular}{l|}
35 \\
36 \\
37 \\
38
\end{tabular} & 53 & $\begin{array}{l}\text { Scott et al. } \\
2000^{24}\end{array}$ & $356(37.8)$ & $587(62.2)$ & $\begin{array}{l}\text { To explore gender differences } \\
\text { in PD patients at disease onset } \\
\text { and at present/ Longitudinal } \\
\text { study }\end{array}$ & $\mathrm{X}$ & & $X$ & & $\begin{array}{l}\text { At disease onset, women reported neck-pain and low back pain more frequently } \\
\text { than men; } 9.3 \text { years later, men reported more writing difficulties, gait problems, } \\
\text { speech problems, increased flow of saliva, and lack of initiative }\end{array}$ \\
\hline $\begin{array}{l}38 \\
39 \\
40 \\
41\end{array}$ & 54 & $\begin{array}{l}\text { Solla et al. } \\
2012^{43}\end{array}$ & $\begin{array}{l}\text { PD: } 65(42) \\
\text { HC: } 51(38)\end{array}$ & $\begin{array}{l}\text { PD: } 91(58) \\
\text { HC: } 81(62)\end{array}$ & $\begin{array}{l}\text { To explore gender differences } \\
\text { in PD/ Cross sectional study }\end{array}$ & $\mathrm{X}$ & $\mathrm{X}$ & $\mathrm{X}$ & & $\begin{array}{l}\text { Women were more likely to present with tremor and had worse UPDRS } \\
\text { instability score; NMSS score was significantly higher women; more frequent } \\
\text { anxiety, depression, fatigue and sleep problems in women, more sexual problems } \\
\text { in men }\end{array}$ \\
\hline
\end{tabular}




\begin{tabular}{|c|c|c|c|c|c|c|c|c|c|c|}
\hline $\begin{array}{l}1 \\
2\end{array}$ & 55 & $\begin{array}{l}\text { Song et al. } \\
2014^{71}\end{array}$ & $170(40)$ & $258(60)$ & $\begin{array}{l}\text { To explore gender differences } \\
\text { in PD/ Cross sectional study }\end{array}$ & $\mathrm{X}$ & & $\mathrm{X}$ & & $\begin{array}{l}\text { No gender differences in motor symptoms; women were more depressed, while } \\
\text { men higher MMSE scores and lower scores for identification on Alzheimer's } \\
\text { Disease Assessment Scale-cognitive subscale }\end{array}$ \\
\hline $\begin{array}{l}3 \\
4 \\
5 \\
6 \\
7\end{array}$ & 56 & $\begin{array}{l}\text { Szewczyk- } \\
\text { Krolikowski } \\
\text { et al. } 2014^{47}\end{array}$ & $\begin{array}{l}\text { PD:184 (38) } \\
\text { HC: } 111(63)\end{array}$ & $\begin{array}{l}\text { PD: } 306(62) \\
\text { HC: } 65(36)\end{array}$ & $\begin{array}{l}\text { To explore the effect of age and } \\
\text { gender in } \mathrm{PD} / \text { Cross sectional } \\
\text { study }\end{array}$ & $\mathrm{X}$ & $\mathrm{X}$ & $\mathrm{X}$ & & $\begin{array}{l}\text { Men showed increased severity and greater symptom symmetricality in the face, } \\
\text { neck and arms and women had more postural problems. Men showed worse } \\
\text { cognitive dysfunction, greater rate of REM behavior disorder, more orthostatic } \\
\text { hypotension and sexual dysfunction, women had more dyskinesias despite higher } \\
\text { LEDD in men. }\end{array}$ \\
\hline $\begin{array}{l}8 \\
9 \\
10 \\
11 \\
12\end{array}$ & 57 & $\begin{array}{l}\text { Umeh et al. } \\
2014^{50}\end{array}$ & $618(35)$ & $1123(65)$ & $\begin{array}{l}\text { To explore gender differences } \\
\text { in types and frequency of drugs } \\
\text { used in PD/ Cross sectional } \\
\text { study }\end{array}$ & & & & & $\begin{array}{l}\text { No gender differences in the type and dose of dopaminergic medications used in } \\
\text { early PD }\end{array}$ \\
\hline $\begin{array}{l}13 \\
14 \\
1\end{array}$ & 58 & $\begin{array}{l}\text { Van Den } \\
\text { Eeden et al., } \\
2003^{18}\end{array}$ & $230(40)$ & $358(60)$ & $\begin{array}{l}\text { To explore the variations of PD } \\
\text { regarding age, gender and } \\
\text { ethnicity/ Cross sectional study }\end{array}$ & $\mathrm{X}$ & & & & The rate to develop PD was $91 \%$ higher in men \\
\hline $\begin{array}{l}15 \\
16 \\
17 \\
18\end{array}$ & 59 & $\begin{array}{l}\text { van der Hoek } \\
\text { et al. } 2011^{73}\end{array}$ & $102(40)$ & $154(60)$ & $\begin{array}{l}\text { To explore the effect of disease } \\
\text { stage, motor subtype and gender } \\
\text { on depression in PD/ Cross } \\
\text { sectional study }\end{array}$ & $\mathrm{X}$ & & $\mathrm{X}$ & & No gender differences in depression \\
\hline $\begin{array}{l}19 \\
20 \\
21\end{array}$ & 60 & $\begin{array}{l}\text { Walker et al. } \\
2012^{83}\end{array}$ & $28(51)$ & $27(49)$ & $\begin{array}{l}\text { To calculate the gender } \\
\text { differences and 1-year survival } \\
\text { rates in PD patients/ Clinical } \\
\text { controlled study }\end{array}$ & $\mathrm{X}$ & & & & $\begin{array}{l}\text { Outcomes for men with PD who have clinically important weight loss are poorer } \\
\text { than for women }\end{array}$ \\
\hline \begin{tabular}{l|}
22 \\
23 \\
24 \\
25
\end{tabular} & 61 & $\begin{array}{l}\text { Wooten et al. } \\
2004^{15}\end{array}$ & $882(48)$ & $955(52)$ & $\begin{array}{l}\text { A meta-analysis with the aim to } \\
\text { calculate the gender related } \\
\text { incidence of PD based on } 7 \\
\text { studies. }\end{array}$ & $\mathrm{X}$ & & & & A 1.5 fold higher incidence of PD in men than women \\
\hline 26 & 62 & $\begin{array}{l}\text { Yamayoto et } \\
\text { al. } 2014^{9}\end{array}$ & $27(42)$ & $37(58)$ & $\begin{array}{l}\text { To explore the gender } \\
\text { differences in urinary symptoms } \\
\text { in MSA/ Retrospective study }\end{array}$ & & & $X$ & & $\begin{array}{l}\text { Men had more nighttime urinary frequency and more severe voiding symptoms } \\
\text { at disease onset }\end{array}$ \\
\hline $\begin{array}{l}28 \\
29 \\
30\end{array}$ & $\Sigma$ & & PD: $12994(41)$ & PD: $18302(59)$ & / & 43 & 23 & 26 & 10 & $\begin{array}{l}\text { In the reviewed studies, men with PD (59\%) outnumbered women with PD } \\
(41 \%) ; 43 \text { studies reported demographic data, } 23 \text { motor, whereas } 26 \text { non-motor } \\
\text { symptoms/signs of PD. The QoL/ADL was specifically reported in } 10 \text { studies }\end{array}$ \\
\hline
\end{tabular}

Table 1. Summary of studies (first author, year and Ref $\mathrm{No}=$ reference number as shown in the reference list) reviewed in the paper. Number and percentage of male and female PD patients (not marked or marked as "PD") and healthy controls (HC) where appropriate, main objectives and main outcome by domain (DEM-demography, MS-Motor Symptoms, NMS-Non-Motor Symptoms, ADL/QoL=Activities of daily living and Quality of Life) as well as summary of the main gender-related results are presented in the table.

$\mathrm{HC}=$ Healthy Controls, $\mathrm{H} \& \mathrm{Y}=$ Hoehn \& Yahr scale, HRQoL=Health related quality of life, Examination, $\mathrm{F}=$ female, LEDD=Levodopa equivalence daily dose, LFP=Local Filed Potentials, LRRK2 = Leucine-rich repeat kinase 2, M=male, MAO-B=Monoamine oxidase B, MMSE=Mini Mental State, MSA=Multiple System Atrophy, STN-DBS = Subthalamic Nucleus Deep Brain Stimulation, PD= Parkinson's Disease, QoL=Quality of Life, PINK1= PTEN induced kinase 1; $\mathrm{PSP}=$ Progressive Supranuclear Palsy, $\mathrm{VP}=$ Vascular parkinsonism 


\begin{tabular}{|c|c|c|c|c|c|}
\hline 4 & Symptom/Sign/Disease feature & $\mathbf{F}$ & & $\mathbf{M}$ & Representative references \\
\hline 61. & Incidence and prevalence & Lower & $<$ & Higher & $\begin{array}{l}\text { Baldereschi et al. } 2000,{ }^{10} \text { Alves et al. } 2009,{ }_{, 1}^{11} \text { Kovacs et al. } 2016,{ }^{13} \text { but see Bergareche et al. } 2004,{ }^{40} \text { de Rijk et al } \\
1997{ }^{41} \text { Nicoletti et al. } 2003^{42} \text { no gender difference }\end{array}$ \\
\hline 2. & Age at disease onset & Later & $>$ & Earlier & Haaxma et al. $2007,{ }^{20}$ but see Baba et al. $2005,{ }^{22}$ Scott et al. $2000^{23}$ no gender difference \\
\hline 8. & Disease progression & Slower & $<$ & Faster & Haaxma et al. $2007,{ }^{20}$ Scott et al. $2000,{ }^{23}$ but see Baba et al. $2005^{22}$ no gender difference \\
\hline 94. & Bradykinesia & Less & $<$ & More & Accolla et al. $2007^{49}$ \\
\hline 105. & Tremor & More & $>$ & Less & Haaxma et al. $2007,{ }^{20}$ Solla et al. $2012^{43}$ \\
\hline 116. & Rigidity & Less & $<$ & More & Baba et al. $2005^{22}$ \\
\hline 127. & Postural instability & More & $>$ & Less & Kovacs et al. $2016,{ }^{13}$ Baba et al. $2005,{ }^{22}$ Solla et al $2012,{ }^{43}$ Szewczyk-Krolikowski et al. $2014^{47}$ \\
\hline 28 & Dyskinesias & More & $>$ & Less & Kovacs et al. $2016,{ }^{13}$ Baba et al. $2005,{ }^{22}$ Colombo et al. $2015^{53}$ \\
\hline 13. & Other complications of dopaminergic therapy (wearing-offs) & More & $>$ & Less & Colombo et al. $2015,^{53}$ for motor fluctuations, Picillo et al. $2016^{57}$ for non-motor fluctutaions \\
\hline 1410 & L-dopa equivalence dose & Lower & $<$ & Higher & Kovacs et al. $2016,{ }^{13}$ Baba et al. $2005,{ }^{22}$ Picillo et al. $2014,{ }^{48}$ but see Umeh et al. $2014^{50}$ no gender difference \\
\hline 1511. & General cognitive abilities & Better & $>$ & Worse & Augustine et al. $2015,{ }^{21}$ Liu et al. $2015,{ }^{61}$ but Gao L et al. $2015,{ }^{51}$ Song et al. $2014^{71}$ \\
\hline 1612. & Verbal memory & Better & $>$ & Worse & Liu et al. $2015^{61}$ \\
\hline 1713. & Visuospatial cognitive abilities & Worse & $<$ & Better & Liu et al. $2015^{61}$ \\
\hline 1814. & Executive functions & Better & $>$ & Worse & Foltynie et al. $2015^{67}$ \\
\hline 1915. & Depression & More & $>$ & Less & Kovacs et al. $2016,{ }^{13}$ Baba et al. $2005,{ }^{22}$ Guo et al. $2013,{ }^{69}$ Picillo et al. $2013,{ }^{72}$ Song et al. $2014^{71}$ \\
\hline 16. & Anxiety & More & $>$ & Less & Liu et al. $2015,{ }^{61}$ Picillo et al. $2013^{72}$ \\
\hline 2017. & Sleep quality, RBD & Better & $>$ & Worse & Bjørnara et al. $2013^{79}$ \\
\hline 24. & Osmic abilities & Better & $>$ & Worse & Liu et al. $2015^{61}$ \\
\hline 2219. & Urinary difficulties & Less & $<$ & More & Guo et al. $2013^{69}$ \\
\hline 2320. & Sexual dysfunction & Less & $<$ & More & Szewczyk-Krolikowski et al. $2014,{ }^{47}$ Picillo et al. $2013^{72}$ \\
\hline 2421. & Orthostatic hypotension & Less & $<$ & More & Szewczyk-Krolikowski et al. $2014^{47}$ \\
\hline 2522. & Pain & More & $>$ & Less & Scott et al. $2000^{23}$ \\
\hline 263. & QoL & Lower & $<$ & Higher & Baba et al. $2005{ }^{22}$ Lubomski et al. $2014,{ }^{84}$ Hariz GM et al. $2013^{85}$ Hariz GM et al. $2003^{86}$ \\
\hline $7^{24}$ & ADL & Lower & $<$ & Higher & Baba et al. 2005, Lubomski et al. $2014,{ }^{84}$ Hariz GM et al. $2013,{ }^{85}$ Hariz GM et al. $2003^{86}$ \\
\hline 25. & Availability of operative (stereotactic) treatment including DBS & Lower & $<$ & Higher & Hariz GM et al. $2011^{88}$ \\
\hline
\end{tabular}

Table 2. Gender-specific distribution of motor, non-motor symptoms and other disease features most frequently reported in studies in PD patients; $\mathrm{ADL}=$ Activities of daily living, $\mathrm{DBS}=$ Deep brain Stimulation, $\mathrm{F}=$ Female, $\mathrm{M}=$ Male, $\mathrm{RBD}=\mathrm{Rem}$ Sleep Behaviour Disorder, $\mathrm{QoL}=\mathrm{Quality}$ of life. 